\title{
The Effect Method of Playing Finger Painting on Creativity Ability And Ability To Espress Languages In Children Age 5-6 Years
}

\author{
Dewi Wulansari1,a*, Siti Masitoh ${ }^{2, b}$, Bachtiar S. Bachrij,c \\ ${ }^{1}$ Postgraduate of State University of Surabaya, ${ }^{2}$ Lecturer, State University of Surabaya, ${ }^{3}$ Lecturer, State University of Surabaya, Indonesia \\ a dewi.17070855097@mhs.unesa.ac.id; deewi.bluesky@gmail.com \\ ${ }^{*}$ Corresponding Author: \\ Whatsapp number: [081357335418]
}

How to Cite : Wulansari, D., Masitoh, S., Bachri, B., S. (2020). The Effect Method of Playing Finger Painting on Creativity Ability And Ability To Espress Languages In Children Age 5-6 Years. International Journal for Educational and Vocational Studies, 2 (1), 128-132. DOI: https://doi.org/10.29103/ijevs.v2i1.2097

\section{ARTICLE HISTORY}

Received: 8 December 2019

Revised: 22 December 2019

Accepted: 16 January 2020

\section{KEYWORDS}

Finger Painting;

Creativity;

Express Language;

\section{ABSTRACT}

This study tries to understand the method of playing finger painting on the ability of creativity and express language of children aged 5-6 years. This research was conducted with a quasi-experimental quantitative method "Pretest-Posttest Control Group Design" in TK Kec. Sukolio Surabaya with a sample of 107 children. Research data obtained through observation, work and documentation, and then analyzed using statistics with ANOVA test with the help of SPSS 25 for Windows. The results showed the method of playing finger painting proven creativity, as evidenced from the Anova test the Fcount value of 187,516 is greater than the Ftable of 3.15. The method of playing finger painting proven against express language, as evidenced by the Anova test the Fcount value of 160,922 is greater than the Ftable of 3.15 . While The method of playing finger painting influences creativity and expresses language, it is evident from the MANOVA test that the Fcount value of 165.122 is greater than the Ftable value of 3.15 . Based on the results of data analysis, it can be concluded that The method of playing finger painting on creativity and express language for ages 5-6 years, and can develop children's abilities with creativity and language of children aged 5-6 years.

This is an open access article under the CC-BY-SA license.

\section{INTRODUCTION}

Early Childhood Education (PAUD) is a coaching effort that is shown to children from birth and up to the age of six years by providing educational stimuli in growing and developing physical and spiritual potential so that children have readiness to enter further education according to Law No. 20 of 2003 National Education System Article 1 Paragraph 14. Children aged 5-6 years of childhood to always want to know the state of the environment, express what is felt with his feelings and each child has different uniqueness and abilities, so that the child's imagination can develop their creativity. At the age of 5-6 years the child enters the preoprational phase in which the child thinks symbolically as a child can paint pictures and words to come up with new ideas and produce work. According to Maria Montessori's theory, children from birth to six years are sensitive periods in developing their abilities.

The ability shown at this time is the creativity and imagination of children (Ministry of National Education,
2010: 5). Creativity is the child creates something that combines thoughts, imagination, ideas, and feelings (Susanto, 2017: 71). According to Sujiono (2010: 13) children's creativity needs to be developed and stimulated by playing methods. The play method is a means and opportunity for children to explore, discover, express their feelings and be creative in a playful way (Parten in Fadlillah, 2017). The ability of creativity aims to hone children in expressing ideas, the work of new experiences. According to Munandar (in Susanto, 2017: 78) the characteristics of creativity are high knowledge, love beauty, imagination, have many ideas, can work alone, and ability in problem solving. So as the child's creativity develops, the child's ability to think indirectly develops the ability to express language.

Language according to Santrock (2009: 70) is a form of communication both verbal and sign using symbols. The process of language acquisition through sudden onset and 
emerges simultaneously with motor skills, social and cognitive pralinguistic (Fromkin and Rodman, 1998: 318). According to Permendikbud No. 137 of 2014 expressing language, children are able to answer questions in a complex manner, create stories from their imagination and express themselves. According to Owens, 1988 (in Otto, 2015: 301) the language of children's tools for telling stories with friends, expressing, playing roles, and attracting attention.

Based on observations, especially kindergarten sabiilus salam, and kindergarten and nur surabaya when making observations on 7-10 January 2019, there are children who find it difficult to express opinions and express ideas in activities that express their imagination, seen during the learning process, there are still many children lack of concentration and less active in learning to hone his imagination. As a result, cognitive abilities in honing creativity and imagination are less developed and have an impact on the ability of language to express ideas.

As for research related to children's creativity. According to Hasibuan, Rahma \& Ningrum, M.A. (2016). The title "the influence of outdoor play and finger painting activities on early childhood creativity". The results of the study are (1) the value of $\mathrm{df}=1$ and the significance level a $=0.05$ obtained the coefficient value $\mathrm{F}=2.134$ and sig. $=$ 0.107 , indicating the significance level above $\alpha=0.05$ for the implementation of learning by outdoor play, (2) the value of $\mathrm{df}=1$ and the significance level of $\alpha=0.05$ obtained coefficient values $\mathrm{F}=1.733$ and sig. $=0.171$, indicating a significance level above $\alpha=0.05$ for the implementation of learning with finger painting activities, and (3) $\mathrm{df}=1$ value and a significance level of $a=0.05$ obtained coefficient values $\mathrm{F}=2.778$ and sig. $=0.101$, indicating the significance level above $\alpha=0.05$ for the implementation of learning by playing outdoors and finger painting activities. According to Soylu, b., Unuvar, P., \& Pisgin, S. (2015) the title "lineal development characteristics of preschool children paintings. The study uses descriptions with a screening model. By checking 125 images of children aged 2-6 years. The results showed the characteristics of paintings in children can develop language skills depending on the environment and providing information to children in thinking skills, so that it can help children express ideas through pictures.

Based on this statement, the learning process needs to use the method of playing its purpose to develop creativity and express language. According to Sujiono (2009: 145) playing in the learning process that can develop a variety of potential in children, not only fine and gross motor skills, but cognitive, language, social, emotion, creativity. The Play Method is the most powerful tool to hone the ability to express language. According to Catron and Allen, the ability to express language can develop their language expression power when interacting (Sujiono, 2009: 63). Playing methods to hone the child's creativity, when playing children receive new experiences, interact with others, and produce a work. The process of playing to develop the ability of creativity and expressing language is to use the method of playing finger painting.

Finger painting is an intermediary for honing abilities, especially in the habit of expression and exploring imagination with a variety of colors and creating new colors so that they are able to express language through stories from painted imaginations. Finger Painting is one of the intermediaries in channeling children's creativity, channeling ideas and ideas in drawings that have been made (Anissa, Ruli, \& Adriani, 2018). Finger painting playing methods develop aspects of physical motor skills, social emotional, arts, language, cognitive and creativity. According to Froebel theory, children are given the opportunity to create, create something with expressions so that children train in the senses, language and play (Rahmat, 2018). Playing finger painting aims to develop expression, enhance children's creativity, develop language expression and respect other people or themselves.

Based on the explanation above, the research would like to test the theory of the method of playing finger painting, by providing learning activities that hone the ability to explore, experiment, express opinions and find different ideas and appreciate work. Aims to maximize the ability of children in developing the ability of creativity and develop confidence to express opinions in accordance with feelings. Researchers arise thinking to conduct research on "the influence of the method of playing finger painting on the ability of creativity and the ability to express language in children aged 5-6 years at TK Sukolilo Surabaya".

\section{METHODS}

This type of research uses quantitative research. Quantitative research is used to examine populations or samples by random sampling techniques, data collection using instruments, quantitative or statistical data analysis to test hypotheses that have been set (Sugiyono, 2009: 14). This research was conducted in the first semester of 2019/2020 in July 2019 conducted in children aged 5-6 years in kindergarten district. Sukolilo Surabaya.

\subsection{Quantitative Methods}

This quantitative research method is a type of experimental research (experimental) is a study with research that is objective, systematic and controlled to predict (Siregan, 2013: 05). Experimental research aims to investigate cause and effect relationships, by exposing one or more experimental groups. Aims to measure the influence of independent variables, namely playing finger Painting (X1) and creativity (Y1) and expressing language (Y2).

Chart 2.1 Free and Bound Variables (Sugiyono, 2009: 68)

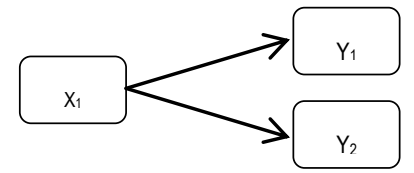




\subsection{Research Design}

Experimental research using the Pretest-Posttest Control Group Design model Table 2.2 Pretest-Posttest Control Group Design (Sugiyono, 2009: 112)

\begin{tabular}{|cl|}
\hline Experiment & $: 01 \times 02$ \\
Control & $: 03-04$ \\
\hline
\end{tabular}

\subsection{Data Collection and Research Instruments}

Collecting research data using observation, work and performance. Observation is data collection done directly describing the condition of the object (Siregan, 2013: 19). The work is the work of children after doing an activity can be in the form of handwork or art. Performance is an assessment that requires children to perform tasks in action that can be observed such as playing finger painting activities.

The instrument is a research tool to obtain, process and interpret information obtained from respondents with the same measurement pattern (Siregan, 2013: 46).

Table 1. Lattice of instruments Espress languages

\begin{tabular}{|c|c|c|c|}
\hline STTPA & Indicators & Declaration Items & No. items \\
\hline \multirow[t]{6}{*}{$\begin{array}{l}\text { Espress } \\
\text { languages }\end{array}$} & \multirow{3}{*}{$\begin{array}{l}\text { Answering more } \\
\text { complex } \\
\text { questions }\end{array}$} & $\begin{array}{l}\text { Can understand the rules in } \\
\text { playing }\end{array}$ & 1 \\
\hline & & $\begin{array}{l}\text { Can implement the rules in } \\
\text { play }\end{array}$ & 2 \\
\hline & & $\begin{array}{l}\text { Can answer the stages of } \\
\text { making finger painting paint. }\end{array}$ & 3 \\
\hline & $\begin{array}{l}\text { Tells the results of } \\
\text { the work }\end{array}$ & $\begin{array}{l}\text { Can tell the work in front of } \\
\text { the class. }\end{array}$ & 4 \\
\hline & \multirow[t]{2}{*}{$\begin{array}{l}\text { Express } \\
\text { self-expression }\end{array}$} & $\begin{array}{l}\text { Can express the expression } \\
\text { of ideas in imagination }\end{array}$ & 5 \\
\hline & & $\begin{array}{l}\text { Can express imagination in } \\
\text { pouring color }\end{array}$ & 6 \\
\hline
\end{tabular}

Table 2. Lattice Instrument of creativity

\begin{tabular}{cccl}
\hline Items & $\begin{array}{c}\text { Corrected Item-Total } \\
\text { Correlation ( } \text { (hitung) }\end{array}$ & rtable & Decision \\
\hline Item 1 & 0,555 & 0.2960 & Valid \\
\hline Item 2 & 0,542 & 0.2960 & Valid \\
\hline Item 3 & 0,15 & 0.2960 & Valid \\
\hline Item 4 & 0,814 & 0.2960 & Valid \\
\hline Item 5 & 0,688 & 0.2960 & Valid \\
\hline Item 6 & 0,851 & 0.2960 & Valid \\
\hline
\end{tabular}

Table 3. Lattice of Instrument attainment

\begin{tabular}{|c|c|c|c|}
\hline STTPA & Indicator & Declaration Item & No item \\
\hline \multirow[t]{3}{*}{ Solve the problem } & \multirow{3}{*}{$\begin{array}{l}\text { Shows } \\
\text { exploratory } \\
\text { activities. }\end{array}$} & $\begin{array}{l}\text { Can explore how to make paint for } \\
\text { finger painting. }\end{array}$ & 1 \\
\hline & & $\begin{array}{l}\text { Can create new colors (secondary } \\
\text { colors) }\end{array}$ & 2 \\
\hline & & $\begin{array}{l}\text { Can combine various colors of } \\
A B C-A B C\end{array}$ & 3 \\
\hline \multirow[t]{3}{*}{ Symbolic Thinking } & \multirow{3}{*}{$\begin{array}{l}\text { Presenting } \\
\text { various objects } \\
\text { in the form of } \\
\text { pictures and } \\
\text { writing. }\end{array}$} & Can generate new ideas in a short time & 4 \\
\hline & & $\begin{array}{l}\text { Can think differently from his friends in } \\
\text { pouring ideas }\end{array}$ & 5 \\
\hline & & $\begin{array}{l}\text { Can create different forms of drawing } \\
\text { and writing from his friends. }\end{array}$ & 6 \\
\hline
\end{tabular}

\subsection{Statistical Data Analysis}

Testing the hypothesis uses ANOVA (Analysis of Variants), namely to test hypotheses with 1 dependent variable and MANOVA (Multivariate Analysis of Variance), namely to test hypotheses with 2 or more dependent variables (Siregan, 2013: 203). If the value of $F_{\text {count }}>F_{\text {table, then Ho is }}$ rejected and $\mathrm{Ha}$ is accepted. If the value of $\mathrm{F}_{\text {count }}>\mathrm{F}_{\text {table, }}$ then $\mathrm{Ho}$ is accepted and $\mathrm{Ha}$ is rejected. If the Asym.Sig value $>0.05$ then the data distribution is declared normal.

\section{RESULTS AND DISCUSSION}

The results of the ability to creativity and express language were obtained from the initial and final observations given to each group which included: Sabiilus salam kindergarten group totaling 30 experimental group children and An-Nur kindergarten totaling 24 control group children. Tk Raden Paku the experimental group totaling 30 children and the TK group Raden Paku the control group totaling 23 children.

\subsection{Test Validity}

Sugiyono (2017: 173) instrument diyatakn valid instrument can measure something that must be accepted.

In creativity using one sample Kolmogorov Smirnov Test with the help of computer software SPSS 25. 
The validity test reveals the language using construct validity, which is the observation sheet per indicator item adjusted to $\mathrm{K} 13$ with the item validity test using the Corrected item-Toral Correlation formula through the help of SPSS 25.0 for window.

Table 4. Anova Test

\begin{tabular}{l|c|c|c|c|c}
\hline \multicolumn{6}{c}{ ANOVA } \\
\hline & $\begin{array}{c}\text { Sum of } \\
\text { Squares }\end{array}$ & Df & $\begin{array}{c}\text { Mean } \\
\text { Square }\end{array}$ & F & Sig. \\
\hline Between & 515,843 & 1 & 515,843 &, 51 & \multirow{2}{*}{, 000} \\
Groups & & & & 6 & \\
\hline Within & 288,848 & 105 & 2,751 & & \\
Groups & & & & & \\
\hline Total & 804,692 & 106 & & & \\
\hline
\end{tabular}

\subsection{Test Reliability}

Research reliability has a certainty or instrumentity in the process of evaluating using SPSS 25 computer software. If Cropabach's Alpa value (a) is greater than 0.60 , the research data is considered to be quite good and

\begin{tabular}{|c|c|c|}
\hline \multicolumn{3}{|c|}{ Reliability Statistics } \\
\hline $\begin{array}{c}\text { Cronbach's } \\
\text { Alpha }\end{array}$ & $\begin{array}{c}\text { Cronbach's Alpha Based on } \\
\text { Standardized Items }\end{array}$ & N of Items \\
\hline, 713 &, 723 & 4 \\
\hline
\end{tabular}

\begin{tabular}{c|c|c}
\hline \multicolumn{3}{c}{ Reliability Statistics } \\
\hline $\begin{array}{c}\text { Cronbach's } \\
\text { Alpha }\end{array}$ & $\begin{array}{c}\text { Cronbach's Alpha } \\
\text { Based on } \\
\text { Standardized Items }\end{array}$ & N of Items \\
\hline, 627 &, 582 & 6 \\
\hline
\end{tabular}

\begin{tabular}{|r|c|c|}
\hline \multicolumn{3}{|c|}{ Reliability Statistics } \\
\hline $\begin{array}{c}\text { Cronbac } \\
\text { h's Alpha }\end{array}$ & $\begin{array}{c}\text { Cronbach's Alpha } \\
\text { Based on } \\
\text { Standardized } \\
\text { Items }\end{array}$ & N of Items \\
\hline, 621 &, 612 & \\
\hline
\end{tabular}

\subsection{Data Analysis Test}

The results of data analysis from the hypothesis test taken in the study. The research hypothesis consists of three hypotheses in the problem statement in chapter 1.

One way Anova test to test the first hypothesis is the $\mathrm{F}_{\text {count }}$ value of $187.516>\mathrm{F}_{\text {table }}$ value of 3.15 and the significance value of $\mathrm{p}$ value $0.000<$ with a level of $5 \%$ or 0.05. $\mathrm{F}_{\text {count }}$ is greater than $\mathrm{F}_{\text {table }}$ so $\mathrm{H}_{\mathrm{o}}$ is rejected and accepts $\mathrm{H}_{\mathrm{a} 1}$ which means that the method of playing finger painting significantly influences creativity.

One way Anova test to test the second hypothesis is the calculated $\mathrm{F}$ value of $160.922>\mathrm{F}$ table value of 3.15 with a level of $5 \%$ or 0.05 . $\mathrm{F}_{\text {count }}$ is greater than $\mathrm{F}_{\text {table }}$ so $\mathrm{H}_{\mathrm{o}}$ is rejected and accepts $\mathrm{H}_{\mathrm{a} 1}$, which means that finger painting significantly influences the language of children aged 5-6 years.

MANOVA test results to test the third hypothesis is the calculated $\mathrm{F}_{\text {value }}$ of $165.122>\mathrm{F}_{\text {table value of } 3.15 \text { with a }}$ level of $5 \%$ or 0.05 . $\mathrm{F}_{\text {count }}$ is greater than $\mathrm{F}_{\text {table }}$ so $\mathrm{H}_{\mathrm{o}}$ is rejected and accepts $\mathrm{H}_{\mathrm{a}}$ which means that the method of playing finger painting significantly influences the ability of creativity and the ability to express the language of children aged 5-6 years.

\section{CONCLUSION}

The results of the data analysis and discussion of the results of the study, then completed with the formulation of the problem and research objectives, it can be concluded that:

1. Finger painting has an effect on creativity with the One-way Anova test proves that Ho is rejected and accepts $\mathrm{Ha}$ which is known from the $\mathrm{F}_{\text {count }}$ value of 187.516 greater than the $\mathrm{F}_{\text {table }}$ of 3.15 .

2. Finger painting has an effect on expressing the language with the one-way Anova test proving that $\mathrm{Ho}$ is rejected and accepting $\mathrm{Ha}$ which is known 
from the $\mathrm{F}_{\text {count }}$ of 160.922 over control of 2.202 .

3. Finger painting affects the creativity of expressing language with the Manova test to test the third hypothesis, namely the $\mathrm{F}_{\text {count }}$ value of $165.122>$

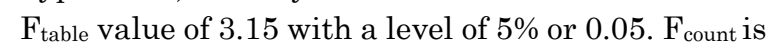
greater than $\mathrm{F}_{\text {table. }}$

\section{REFERENCES}

Asmawati. L. (2017). Enhancing Early Childhood Creativity Through Integrated Intelligence Based on Multiple Intelligences. Journal of Early Childhood Education. 11(1). doi: 10.21009/JPUD.111.10.

Anissa, Ruli, \& Andriani. (2018). The Influence of the Finger Painting Method on Literacy Ability in Children Aged 5-6 Years. Downloaded from http:/eprints.uns.ac.id >K8113008_abst....

Anita. (2015). Early Childhood Language Development. Al-shifa Journal. Vol.06 No. 02. ISSN:2087-8621.

B.E.F. Montolalu. (2009). Play and Play for Children. Jakarta: Universitas Terbuka.

Chaer, Abdul. (2009). Pengantar Semantik Bahasa Indonesia. Jakarta: Rineka Cipta.

Depdiknas. (2000). Reading and writing games in kindergarten. Jakarta: Depdiknas.

Depdiknas. (2003). Undang-undang RI No. 20 Tahun 2003. About the National Education System. Jakarta: Depdiknas.

Depdiknas. (2005). Guidelines for learning in kindergartens.Jakarta: Depdiknas.

Fromkin, Victoria \& Robert Rodman. (1998). An Introduction to Language. USA: Harcourt Brace Company

Hurlock, Elizabeth B. (1978). Developmental Psychology An Approach Throughout Life Spans. Jakarta. Erlangga.

Hasibuan, Rahma \& Ningrum, M.A. (2016). Effects of Outdoor Play and Finger Painting Activities on Early Childhood Creativity. Journal of Education.1(1), 72-80. ISSN: 2527-6891

Jamaris, M. (2006). The development and development of kindergarten children. Jakarta: Gramedia.

Jalongo, Mary Renck. (1992). Early ChildhoodLanguage Arts. Singapore: Allyn and Bacon.

Lucrezia, C., Sara, P. \& Carey, J. (2014) Paint on The Finger or Paint on The Screen: A Comparative Study. ScienceDirect. Procedia Sosial and Behavioral Sciences.140 (2014) 376-380.

Ningsih, E. (2013). The Use of Role Playing Methods in Fostering Early Childhood Language Skills. Jurnal Emprowerment. Vol 2, No.2 ISSN:2252-4738.

Otto, Beverly. (2015). Language Development in Early Childhood. Jakarta. Kharisma Putra Utama.

Pamadhi, Hajar dan Sukardi S, Evan. (2010). Children's Art Skills. Jakarta: Kencana

Santrock, John W. (2007). Child development . Jakarta. Salemba Humanika.

Santrock, John W. (2009). Developmental psychology .
Jakarta: Salemba Humanika.

Santrock, John W. (2012). Developmental psychology . Jakarta: Salemba Humanika.

Siregar. (2013). Quantitative Research Methods. Jakarta: Kencana Prenada Media Group.

Soylu, b., Unuvar, P.,\& Pisgin, S.(2015). Lineal

Development Characteristics of Preschool Children Paintings. ScienceDirect. Procedia Sosial and Behavioral Sciences 174 (2015) 687-692.

Tagir, R. (2003). Multiple Intelligences (mengenali dan merangsang potensi kecerdasan anak). Jakarta:PT. Grafika Multi Warna.

Sugiyono. (2012). Statistics for Research.Bandung: Alfabeta. 